\title{
Del aula y el magisterio a la "Revolución Pingüina"
}

\section{Olimpia Riveros Ravelo ${ }^{1}$}

El asombro de la sociedad chilena ante la llamada "revolución pingüina" (expresión que no me agrada pues tiene un cierto sesgo peyorativo) revela un absoluto desconocimiento o desconexión con el mundo real de la educación.

Por años el magisterio nacional en forma organizada ha venido diciendo su voz crítica a los procesos antidemocráticos que se viven en educación. Para tratar de ser fieles a la historia es preciso recordar que la AGECH, Asociación Gremial de Educadores de Chile, nace el año 1981 como instancia de resistencia a la municipalización y llega a agrupar a más de 10 mil profesores que en dictadura asumen el compromiso con la educación pública con un rol del Estado, antiprivatización y por cierto antidictatorial.

Esa organización se incorpora al Colegio de Profesores a partir de 1987 obligándolo a un proceso de democratización que aún no termina, y permitió que los educadores chilenos pudiéramos hacer un aporte significativo a lo que llamamos en esa época "recuperación de la democracia."

El discurso de los maestros y maestras no varió. Educación pública, laica, gratuita para todos y todas. Culminó un proceso de fortalecimiento de esta lucha en el Congreso nacional de educación de 1997, que en su fase final contó incluso con la presencia del Presidente de la República de la época, Eduardo Frei, quien jamás leyó las resoluciones ni opinó al respecto. La misma suerte ha corrido nuestro Congreso con las otras máximas autoridades del país.

Este discurso silenciado por mucho tiempo pero sostenido en el trabajo cotidiano de miles de maestros en escuelas y liceos de alguna manera, no siendo el único factor, permitió la forja, también silenciosa de la movilización de nuestros estudiantes secundarios que estalla, oh sorpresa con una fuerza incontenible, 
con capacidades que a nuestros jóvenes se les desconocían. Todo esto para señalar que los procesos políticos sociales existen y son reales y tuvieron su expresión legítima con apoyo de padres, madres, profesores que se pusieron al lado de los jóvenes conscientes de que las demandas eran justas y urgentes. Poco se dice acerca de las demandas que los estudiantes habían presentado a las autoridades y que nunca fueron consideradas. Es la sordera crónica de nuestra democracia imperfecta uno de sus rasgos más característicos. Cuando señalo que jamás la actual Presidenta de la República ha recibido a nuestro gremio ni para el más mínimo intercambio muchas personas no lo pueden creer.

Los estudiantes secundarios dijeron e hicieron lo que los educadores veníamos sólo diciendo. Libres de la problemática de la lucha por la sobrevivencia, al menos directamente, estuvieron coordinados, sólidos y solidarios mostrando estrategias, coordinaciones, pasos tácticos, que revelaban capacidad e inteligencia. Cosa que cada día los profesores pueden comprobar en la sala de clases aunque no siempre se atrevan a abrir esos espacios más auténticos de participación. Las secuelas de la dictadura están presentes de manera muy patente en las escuelas y liceos y los profesores en gran medida siguen siendo presas del miedo a perder la pega, a quedar indefensos, a ser delatados o perseguidos laboralmente. La inestabilidad laboral se ha instalado en el sistema escolar junto con el retroceso de políticas de igualdad de oportunidades. La inequidad del sistema, la segmentación segregadora que ha producido la municipalización fracasada, el avance privatizador y la mantención del concepto de educación como "servicio" o mercancía se viven cada día en el sistema escolar, agravado por cierto con la figura del financiamiento compartido, que no es secuela dictatorial y es un engendro neoliberal de la Concertación.

El curso posterior de los acontecimientos ya es conocido. Con mecanismos seudoparticipativos, Consejo Asesor presidencial, se empieza a ocultar el fondo del problema y avanza la política de los acuerdos políticos cupulares. Los actuales proyectos de ley en el parlamento no representan los intereses de las grandes mayorías nacionales, ni de los estudiantes, ni de los educadores, ni de los padres y apoderados que seguirán agobiados por el costo de la educación en el presupuesto familiar si estos proyectos prosperan. 
La insuficiencia de nuestro sistema político queda a la vista, con el pretexto de que es lo más que pudimos, el gobierno cede ante presiones de los poderes representados por la Alianza que incluye al nuevo empresariado de la educación. En lugar de plantear sus aspiraciones y defender sus compromisos con los ciudadanos que los respaldaron cae en el juego de los manejos, canjes, acuerdos, trueques, y luego pretende que la ciudadanía le siga siendo incondicional.

Los estudiantes estarán alertas este presente año. Los educadores también. Una clara voluntad de cambios reales se ha venido abriendo paso en la conciencia nacional y si no entran malas manos en estos acuerdos movilizadores será este año 2009 un hito en la historia nacional por la real recuperación de la democracia.

La contribución de la revolución de nuestros estudiantes ha sido inmensa y todavía no terminan sus efectos.

\section{Nota}

1 Dirigente nacional del Colegio de Profesores. 